\title{
Conserving the Simalungun Language Maintenance through Demographic Community: The Analysis of Taboo Words Across Times
}

\author{
Ridwin Purba ${ }^{1,2}$, Berlin Sibarani ${ }^{1}$, Sri Minda Murni ${ }^{1}$, Amrin Saragih $^{1}$, Herman $^{3}$ \\ ${ }^{1}$ English Applied Linguistic Program, Post Graduate School, Universitas Negeri Medan, Indonesia \\ ${ }^{2}$ English Education Department, Universitas Simalungun, Pematangsiantar, Indonesia \\ ${ }^{3}$ English Education Department, Universitas HKBP Nommensen, Medan, Indonesia \\ Correspondence: Ridwin Purba, English Education Department, Universitas Simalungun, Pematangsiantar, \\ Indonesia.
}

Received: September 24, 2021

Accepted: October 13, $2021 \quad$ Online Published: October 26, 2021

doi:10.5430/wjel.v12n1p40

URL: https://doi.org/10.5430/wjel.v12n1p40

\begin{abstract}
The research was intended to describe the use of Simalungun taboo words across times in Simalungun (1930-2021). The language of Simalungun is spoken by people living outside the district of Simalungun, North of Sumatera and other people. This research was carried out in a multi-case descriptive qualitative design. Descriptual qualitative research design was defined as a social science research approach that emphasised the collection, use of inductive thinking and understanding of descriptive data in natural environments. While multi case is defined as a study which is using two or more subjects, settings, or depositories of data (Bogdan \& Biklen, 1982). Documentation, interviews and observations of participants were used to collect data on linguistic taboos. The data sources were collected from 45 informants of different ages (1930-2021) and sexes who reside in Pematangsiantar, Pematangraya and Saribudolok. After having analyzed the collected data, the research finding showed that there were 62 words out of 106 the taboo words of ten categories: sexual organ, sexual activity, cursing, swearing, calling people, action, disease, dwelling ghost and name of God which were used stably across time (from 1930 to 2021) in Simalungun are 62 words, out of 106 words.
\end{abstract}

Keywords: conserving, Simalungun language, demographic community, taboo words, across times

\section{Introduction}

Language can not be seperated from the socioculture where the language exists. The socioculture of a particular society will influence the speakers of its language which means that speakers must consider the socioculture of a society so that they can use the language properly. One of the cultural aspects that people must be aware of is the case of taboo. Taboo can be found and exists in many speech communities. Taboo is one way in which the society expresses its disapproval of certain types of behaviors that are considered harmful to its members for either supernatural or moral reasons (Wardhaugh, 1986). Linguistic taboos are linguistic forms that can not be uttered because they are considered to be improper speech forms. Consequently, the speakers will try to avoid using the linguistic taboo terms not to be considered impolite. Of course, those who break the taboo in attempt to show freedom from such restrictions or to expose the taboos will be punished and scorned by their communities. The penalty for breaking the taboo words and phrases can be severe such being cursed, scorned and the like.

Language has special powers to heal illness, to avoid evil, to bring good to oneself and damage to an enemy (Hashimee, 2020; Herman \& Purba, 2021; Mpofu \& Maphalala, 2020; Purba \& Herman, 2020; Qasemi, 2020; Sukirlan, Raja, Setiyadi, \& Agustin, 2020). Since old times, it has been the belief in the fact that the words objects, persons and spirits control human activity through history. Such language should usually be used very carefully and pronunciation and wordings should be carefully considered. They are even avoided by the people. When people talk about these things, they are discussed very broadly.

As a heterogenous country, Indonesia consists of many different ethnic groups, religions, culture and languages. The heterogeneity in Indonesia must remain in keeping with the idea that Indonesia is a nation state that recognizes the existence of their various communities so as to ensure that conflicts between the members of the indonesian people do not develop. This idea is stated in the Indonesian 1945 Constitution (UUD 1945). These various different cultures 
stretch from Sabang to Merauke. The plurality is expressed in Bhineka Tunggal Ika in which the various cultures are acknowledged and have the right to be developed to contribute and enrich the national culture. The government has the policy and responsibility to develop the national culture continuously.

In terms of language, hundreds of local languages spread around the country. The local languages, as communication device among the local, play an important role in life. That is why many Indonesian people use local languages and feel proud of using the language among the members of their groups. It is one way to maintain the cultural heritage which still exists among the members of its community. However, many of the ethnic group cultures become detached from its existence. The crucial problem is how to maintain and develop the various local cultures so that they can be transfered to the young generations. The local cultures are the elements of the national culture that need to be taken care of in order to develop the national culture.

The Simalungun culture is one of the national cultures in Indonesia that is still alive and practiced by the group members in its customary seetings which are called adat. In birth, wedding ceremonies and funeral activities, the Simalungun cultural values are still performed (Purba, 1998). Also, some of the Simalungun cultural activities such as Tortor (dancing), limbaga (proverbs), tangis-tangis (lamentation), doding (songs), etc are still alive and enjoyed (Purba, 1998). The Simalungun language (SL) is spoken not only by the Simalungun ethnic group, but also by residents of North Sumatera's Simalungun district. The Simalungun language supports the Simalungun culture in terms of arts, customs, laws, religion, etc. As a means of communication, the Simalungun language is used to express desires, ideas, feelings and the like.

In most civilizations, language tabuism exists, with Tabu terms being generally culturally distinctive and related to corporal functions or sacred cultural characteristics. These words are avoided as inadequate and emotional they are considered. Some taboo words and phrases denote objects that are not to be mentioned in a casual way or perhaps not to be mentioned at all. In many communities, the names of people are taboo in certain circumstances or to certain people, such as the Cree Indian, who does not speak the names of his sisters and other female relatives. Another area of taboo is the prohibition of so-called obscene forms. Another type of taboo is avoiding ominous speech forms that refer to something painful or dangerous. The words die and death are avoided (if anything should happen to me). In some communities, the names of game animals are avoided, either during the hunt or more broadly (Bloomfield, 1964) in everyday life.

Taboo words and phrases also exist in the Simalungun language and there are some reasons which motivate the writer to conduct the research on taboo. Actually, in the Simalungun language there are some aspects of language which can be studied such as songs, lamentations, proverbs, etc., yet the writer will concentrate on taboo. The case of taboo is influenced by the sociocultural background, and taboo is still practiced among the Simalungun community, which is distinct from other places. Taboo language is considered as the prohibition to use words or expressions which do not conform the ethical, philosophical, religious and social norms of the Simalungun community. Even though there are some similarities of taboo in the Simalungun community and in the other speech community, there are also differences which cause the occurrence of taboo in the Simalungun community.

In Simalungun language, taboos can be categorized into the prohibition of objects, persons and behaviors. The linguistics taboo can be regarded as sacred and dangerous as well. They certainly happen because of the background of the Simalungun community such as ethnic groups, ethics, religion, philosophy etc. The consequence of those who use linguistic taboos in a social interaction is that they will be scorned by the community. For example, it is not common for one to call his/her uncle's name, because uncle is believed as the man who gives blessing to his sister's family. The cultural system causes one to avoid not calling his/her uncle's name. In this ways taboos can hamper communication between a speaker and hearer and raise conflict between the speaker and hearer. In the global era, even though it should be questioned whether this kind of taboo should be maintained, it is necessary to keep the linguistic taboos as a cultural richness.

The success of the former Dutch and German missionaries in converting the Simalungun people through the process of evangelization and the downfall of the Simalungun kingdoms caused the traditional beliefs to disappear (Saragih, 1979). The missionaries built schools where the Simalungun people got education and outside information. Since that time, the Simalungun people were open toward the outside information. As a consequence, some of the taboo cased relate to the laws, customs, traditional religion, ethics and philosophy of the Simalungun society decrease.

In the globalization era, the cultural values become loose because of the arrival of foreign culture. Cultural values which are attached to language might also become loose. Possibly, the tabooed words and phrases which exist in the Simalungun language will disappear because of the foreign influence. It is a must to keep the cultural values in the Simalungun language because those values will not disappear from its existence. In line with this, some aspects such Published by Sciedu Press 
as: what we want to say, how we want to say it and the specific sentence types, words and sound should be considered. It means that the speaker and hearer should speak appropriately and politely so that the interaction will proceed smoothly avoiding any conflict and disharmony.

Although taboo words form a part of every culture and language, and everyone uses the taboo word for one reason or another at some time in their lives, the topic is understudied because of its sensitivity, which implies it is not suitable for academic studies. In any societal context, on the other hand, we hope that the study of language taboo, from a social and cultural angle, will add a new dimension to our understanding of the psyche of the human being, as communal Members react to the world around them by establishing prohibitions and language penalties to prevent behavior and some objects. Moreover, in the community's lexicon, taboo terms are still used, despite language control, as they reinforce the social fabric and group identification by providing a feeling of common social and cultural faith. The members of society are distinguished from other societies. And if we understand why there's a taboo, we can comprehend the ideals and reality of society - it provides a lot of information about how people feel about specific problems. It also sheds light on the social, religious and metaphysical practices and political framework of the community.

Changes also happens in taboo language as Webster (1942) argues that taboo systems, which reached the acme of development in Polynesia, did not long survive the opening up of then islands to European settlement. The abrogation of the taboo system by the Polynesian was the consequence of their intercourse with foreigners especially with the missionaries; the old beliefs persist to some extent among these islanders lest affected by European influence. The decline and obsolescence of taboos in Polynesia throws lights on the process which led to their elimination by civilized people in the past ages. With the progress of mankind prohibitions which had outlived their usefulness were gradually dropped, while those with some sense behind them were retained as religious interdictions, as moral precepts, or as legal enactment. This research is intended to identify taboo words are used across times from 1930 to 2021 in Simalungun in in three different areas.

\section{Review Literature}

Taboo, derived from the Polynesian tabu, is one of the few words that Pacific Islander languages have contributed to modern speech. In English, it can be a noun, an adjective, a participle, or a verb: a taboo is a prohibition; an object taboo or tabooed is an object that is prohibited; and to taboo is to put something under a prohibition. The Polynesian word had only adjectival meaning, and the substantive and verbal forms were expressed through derivative words and phrases. Tabu appears to be the Tongan word; tapu is derived from ta, to mark, and pu, an adverb of intensity. Because sacred things and places were commonly marked in a peculiar manner, in order for everyone to know that they were sacred, the compound word tapu means no more than'marked thoroughly/ and only came to signify sacred or prohibited in a secondary sense; because sacred things and places were commonly marked in a peculiar manner, in order for everyone to know that they were sacred (Webster, 1942).

Taboo words (Allan \& Burridge, 2006) are to be avoided according to Allan and Burridge. In other words, on a specific occasion a taboo is censored, because the speaker fears that the listener will be beaten and the face lost. We mean words which can be regarded as insulting with taboo words. Taboo words and taboo language are hard to distinguish because they often overlap. For the sake of this study, we defined taboo words as words that are forbidden to use, whereas taboo language refers to forbidden language use or function, such as swearing. As an example, a man of African descent may come across and call him a nigger.

A taboo is any prohibition that carries no penalties other than the anxiety and embarrassment caused by a violation of deeply ingrained custom (Steiner, 1956). The violation of taboo in a society causes one to be embarrassed and anxious even though society does not give any penalties to the violators, because taboo is a custom which has a very strong position in a society and cannot be changed. By becoming aware that he has violated a custom, the violator imposes penalties on himself.

Crystal (1992) mentions that taboos are words that are not allowed to be used in a society. One who is using the words will cause an offence to the interlocutors. The interlocutors may feel hurt, angry, or upset (Steiner, 1956). The violation of taboo in a society causes one to be embarrassed and anxious even though society does not give any penalties to the violators, because taboo is a custom which has a very strong position in a society and cannot be changed. The violator himself provides the penalties to himself by realizing that a custom has been violated by him.

Trudgill (2000) defined taboo as "behavior that is thought to be supernaturally forbidden, or that is regarded as immoral or improper: it deals with behavior that is prohibited or inhibited in an apparently irrational manner." Taboo refers to things that are not said, particularly words and expressions that are not used. In practice, this simply means 
that there are inhibitions about the normal use of items of this type - if they were not said at all, they would almost certainly disappear from the language. This demonstrates that a society's values can have an impact on its language.

Scholars provided evidence of various types of linguistic taboos, with some focusing on just one and others covering a wide range. Taboos are classified into two types. One is known as verbal taboo, while the other is known as nonverbal taboo or behavioral taboo. The term "verbal taboo" refers to the total or partial prohibition of using certain words, expressions, and topics in social interaction. The behavioral taboo, also known as the nonverbal taboo, refers to daily behavioral patterns that people are unable to engage in because traditional values or social customs strongly discourage such behavior. In fact, adhering to such behavioral taboos implies that cultural custom, religious belief, and ethical norms must all be followed. This study focuses on verbal taboo, specifically taboo words and phrases.

As mentioned above, the term taboo refers generally to something forbidden in society, culture or religion. According to Mercury (1995) there are numerous sorts of tabuistic words heard in society now and especially more in Western society, but four primary categories include: the taboo or obscenity, profanity, blasphemy, export, cursing, etc. There are four sorts of tabuistic expression according to Crystal (1992): profanity, blasphemy, obscenity, and extortion. Hudson (1982) defines the field of taboo by stating that there should have been considerable research from socio-linguists in this whole field of taboo and semi-taboo (slang, profanity, insults) which should tell us a lot about language's connection to society.

Gramley and Pätzold (1992) indicate that the tabeo-specific lexicon was also explored. Men have a higher probability of using obscene language, than women who employ impersonal or neutral terms. Furthermore, the use of women is generally perceived as unduly favorable, as indicated by Gramley and Pätzold (1992), but the use of men's vocabulary is considered as more aggressive and profane. In general men employ around three times the taboic language of women, using stronger taboic terms (Allan \& Burridge, 2006; Gramley \& Pätzold, 1992). In addition, Allan and Burridge (2006) say that both men and women are more prone to employ tabo language in the same sex company. They also point out that profanity frequently takes place from a young age, regardless of the gender of the speaker.

Changes also happens in taboo language as Webster (1942) argues that taboo systems, which reached the acme of development in Polynesia, did not long survive the opening up of then islands to European settlement. The abrogation of the taboo system by the Polynesian was the consequence of their intercourse with foreigners especially with the missionaries; the old beliefs persist to some extent among these islanders lest affected by European influence. The decline and obsolescence of taboos in Polynesia throws lights on the process which led to their elimination by civilized people in the past ages. With the progress of mankind prohibitions which had outlived their usefulness were gradually dropped, while those with some sense behind them were retained as religious interdictions, as moral precepts, or as legal enactments.

Furthermore, it is likely that various taboos evolved into etiquette rules whose violation results in only vague public disapproval or, at best, some degree of social ostracism. Every society has its own standards of good form, which, if traced back far enough, can often be found to be based on primitive notions of pollution or sanctity. Such ideas may have influenced politeness rules, court ceremonial observances, euphemisms in our speech, and even our sanitary regulations.

\subsection{Simalungun Taboo Language}

In Simalungun land as well as in other parts of Indonesia, there are cases of taboo which can be found and they have existed long time ago. The taboo among the Simalungun community is known as marobu. Marobu has the meanings of pantang (taboo) and larangan in the Simalungun dictionary written by Saragih (1981). (prohibited). Marobu originally came from a ceremony which was done after having finished ploughing in the garden that the village people were prohibited to work and those who violated this prohibition would be fined as the punishment.

The existence of taboo in Simalungun community may be similar to what are found in other places, but on the other hand, it may be different. There are some cases which are considered taboo in the midst of the Simalungun community. Mentioning dirty words, holding one's head, receiving something with left hand, insulting people, scolding, swearing, etc., are considered taboo. Holding one's head is taboo, because head is counted of high value by the Simalungun people. One will be angry or feel insulted when his/her head is held.

The research on taboo language is still relevant though we are living in modern and global world. There are bound cultural values that are inherent to language which control and regulate people in communication that the communication will be running well not causing conflict or tension. Simalungun people are still faithful to their culture and philosophy as to avoid marobu in communication with other people. 


\subsection{Functions of Taboo Language}

The use of taboo words is usually associated with intense emotion. As a result, speakers use them to express strong emotions, and listeners respond with similarly strong emotions and reactions. Speakers who are aware of the power of taboo words to elicit strong reactions may purposefully use them to shock their audience. People may use taboo words to express pent-up emotions like anger or frustration. Persons who have occupations that are stressful also tend to use taboo words since using them relieves tension. Anthropologist Pilcher (1972) who studied a community of longshoremen in the city of Portland, Oregon, USA, observed that there was a high degree of taboo word use among these men when they were working on board the ship since such work was quite hazardous and stressful

\subsection{Demography}

Demography is the scientific research on the size, distribution and composition of a human population as well as the variables influencing these factors. Five features of human population are the subject of demographics: 1) size, (2) distribution, (3) composition, (4) population dynamics, and (5) social and economic causes, as defined. The amount of people in a particular location is simply called population size at a given period. The manner in which the population is distributed at any particular time in geographical space is known as population distribution. The population composition is called the number of persons in each sex, age and other demographic category.

\section{Research Methods}

This research was conducted with descriptive qualitative design with a multi case type. Descriptive qualitative research design was defined as a method of conducting social science research that emphasizes gathering descriptive data in natural settings, employing inductive reasoning, and emphasizing understanding the subjects' point of view (Azmi, Hua, Abdullah, \& Azman, 2021; Bogdan \& Biklen, 1982; Herman, Murni, Sibarani, \& Saragih, 2019; Madzlan, Seng, \& Kesevan, 2020; Van Thao, Herman, Ha, Thuy, \& Tho, 2020). While multi case is defined as a study which is using two or more subjects, settings, or depositories of data (Bogdan \& Biklen, 1982; Van Thao, Herman, Napitupulu, Hien, \& Pardede, 2021). This study, by applying the design, was intended to describe the phenomena involved in this research with thick word description. The words recognition by Simalungun people across demography community and across time was taken as two cases. The ways of use of the currently recognized taboo words across demographic community and time was also considered as two cases.

The research was conducted in three areas. The first area was district Pematangsiantar where the Simalungun people live there and some of them migrated from Pematangraya, Simalungun area. The second area was Raya's subdistrict. The Pematangraya subdistrict was chosen as the research location because it is the capital of Simalungun district, and Pematangraya was the center of Christian evangelization of Christian religion by German missionaries in 1903. Since 2015, Pematangraya has been the capital of Simalungun district, and there have been changes there. The third area is the Saribudolok subdistrict, which is surrounded by Simalungun and Karo districts.

Documentation, interviews, and participant observation were used to collect data on linguistic taboos (Bogdan \& Biklen, 1982). Interview provided access to the context of people's behavior and in-depth understanding the meaning of that behavior. The researcher interviewed the key informants who spoke and understood the Simalungun culture and language especially taboo language, lived in the Simalungun area, and could answer to related questions. There were 45 people of different ages from different area (Pematangsiantar, Pematang Raya and Saribudolok) to be interviewed: By observation, the writer observed the people's behavior in certain situations, i.e. in the market, in disputes, and in emotional conditions. By documentation, the writer listed and recorded the linguistic taboos from books, journals, Simalungun dictionary, thesis and other scripts from the Simalungun museum which is located in Pematangsiantar North Sumatera, Indonesia.

\section{Results and Discussions}

In order to describe types of taboo words used in Simalungun from 1930 - 2021, the data of this study, namely the taboo words, are categorized based on the theory of Jay (1992). According to this theory, taboo words are classified into 10 categories, they are: sexual organ, sexual activity, excretion, cursing, swearing, calling people, action, dwelling ghost, disease, and God.

\subsection{Sexual Organ Taboo Word Category}

In the sexual organ taboo word, there are 8 sexual organ taboo words are stably used, namely 1) bujang, (2) hayang, (3) janggut, (4) kontol, (5) neneng, (6) susu, (7) totong, and (8) natu. 
Table 4.1. Sexual Organ Taboo Word Category

\begin{tabular}{|c|c|c|c|c|}
\hline \multicolumn{5}{|c|}{ Sexual Organ Category } \\
\hline 1930-1940 & 1941-1960 & 1961-1980 & 1981-2000 & $2001-2021$ \\
\hline Adop & Not Used & Adop & Not Used & Not Used \\
\hline Bikuna & Bikuna & Bikuna & Not Used & Not Used \\
\hline Bujang & Bujang & Bujang & Bujang & Bujang \\
\hline Dila-dila & Dila-dila & Dila-dila & Not Used & Dila-dila \\
\hline Dildil & Dildil & Dildil & Not Used & Not Used \\
\hline Dotak & Dotak & Dotak & Not Used & Not Used \\
\hline Dugal & Dugal & Dugal & Not Used & Not Used \\
\hline Gundala & Not Used & Gundala & Not Used & Not Used \\
\hline Hayang, & Hayang & Hayang & Hayang & Hayang \\
\hline Hosah & Hosah & Hosah & Not Used & Hosah \\
\hline Hundulan & Hundulan & Hundulan & Not Used & Hundulan \\
\hline Janggut & Janggut & Janggut & Janggut & Janggut \\
\hline Kontol, & Kontol & Kontol & Kontol & Kontol \\
\hline Mamang & Mamang & Mamang & Not Used & Not Used \\
\hline Natu, & Natu & Natu & Natu & Natu \\
\hline Neneng & Neneng & Neneng & Neneng & Neneng \\
\hline Nunuk & Nunuk & Nunuk & Nunuk & Not Used \\
\hline Not Used & Nunung & Nunung & Not Used & Nunung \\
\hline Panei & Not Used & Not Used & Not Used & Not Used \\
\hline Sanei & Not Used & Not Used & Not Used & Not Used \\
\hline Susu & Susu & Susu & Susu & Susu \\
\hline Not Used & Tappakan & Tappakan & Not Used & Not Used \\
\hline Tete & Tete & Tete & Not Used & Tete \\
\hline Tombom & Tombom & Tombom & Not Used & Not Used \\
\hline Totong & Totong & Totong & Totong & Totong \\
\hline 23 & 21 & 23 & 9 & 13 \\
\hline
\end{tabular}

\subsection{Sexual Activity Taboo Word Category}

There are four categories of sexual activity words identified: 1) mamorus-morus, (2) mandugal, (3) martettet, and (4) martettet hayang, which are used consistently by people ranging in age from 102 to 16 years. The use of taboo language change with the development of human society to satisfy the need of human for communication. Taboo words used in Simalungun are closely related to the culture of Simalungun and the specific context in which the taboo words are used

Table 4.2. Sexual Activity Taboo Word Category

\begin{tabular}{|c|c|c|c|c|}
\hline \multicolumn{5}{|c|}{ Sexual Activity } \\
\hline 1930-1940 & $\mathbf{1 9 4 1 - 1 9 6 0}$ & $\mathbf{1 9 6 1 - 1 9 8 0}$ & $\mathbf{1 9 8 1 - 2 0 0 0}$ & $\mathbf{2 0 0 1 - 2 0 2 1}$ \\
\hline Mamorus-morus & Mamorus-morus & Mamorus-morus & Mamorus-morus & Mamorus-morus \\
\hline Mandotak & Mandotak & Mandotak & Mandotok & Not Used \\
\hline Mandugal & Mandugal & Mandugal & Mandugal & Mandugal \\
\hline Marsandut & Marsandut & Marsandut & Marsandut & Not Used \\
\hline Matettet. & Matettet & Matettet & Matettet & Martettet \\
\hline Martettet haying & Martettet hayang & Martettet hayang & Martettet hayang & 4 \\
\hline 6 & 6 & 6 & 6 & \\
\hline
\end{tabular}

\subsection{Excretion Taboo Word Category}

In the category of (c) excretion, only three words are used stably across time (from 1930 to 2021), namely (1) te, (2) titis, and (3) tois.

Table 4.3. Excretion Taboo Word Category

\begin{tabular}{|c|c|c|c|c|}
\hline \multicolumn{5}{|c|}{ Excretion } \\
\hline 1930-1940 & $1941-1960$ & $1961-1980$ & $1981-2000$ & $2001-2021$ \\
\hline Dikis-dikis & Dikis-dikis & Dikis-dikis & Dikis-dikis & Not used \\
\hline Hulmah & Hulmah & Hulmah & Not Used & Not Used \\
\hline Polak-polak & Polak-polak & Polak-polak & Not Used & Not Used \\
\hline Te & Te & Te & Te & Te \\
\hline Titis & Titis & Titis & Titis & Titis \\
\hline Tois & Tois & Tois & Tois & Tois \\
\hline 6 & 6 & 6 & 4 & 3 \\
\hline
\end{tabular}




\subsection{Cursing Taboo Word Category}

In the category of cursing taboo word, only four words used stably across time (from 1930 - 2021), they are (1) ulumin, (2) pukimakmu, (3) sundut ma ho, and (4) dapot ko do holi nai hatahonmai,

Table 4.4. Cursing Taboo Word Category

\begin{tabular}{|c|c|c|c|c|}
\hline \multicolumn{5}{|c|}{ Cursing } \\
\hline 1930-1940 & 1941-1960 & 1961-1980 & 1981-2000 & 2001-2021 \\
\hline Buatan ni polong! & Buatan ni polong! & Buatan ni polong! & Buatan ni polong! & Mulih ma ho! \\
\hline Buatan ni sampar! & Buatan ni sampar! & Buatan ni sampar! & Buatan ni sampar! & Not Used \\
\hline Mulih ma ho! & Mulih ma ho! & Mulih ma ho! & Mulih ma ho! & Not Used \\
\hline Ulumin! & Ulumin! & Ulumin! & Ulumin! & Ulumin! \\
\hline Pukimakmu! & Pukimakmu! & Pukimakmu! & Pukimakmu! & Pukimakmu! \\
\hline Sundut ma ho! & Sundut ma ho! & Sundut ma ho! & Sundut ma ho! & Sundut ma ho! \\
\hline $\begin{array}{c}\text { Dapot ko do holi na } \\
\text { ihatahon mai! }\end{array}$ & $\begin{array}{c}\text { Dapot ko do holi na } \\
\text { ihatahon mai! }\end{array}$ & $\begin{array}{c}\text { Dapot ko do holi na } \\
\text { ihatahon mai! }\end{array}$ & $\begin{array}{c}\text { Dapot ko do holi na } \\
\text { ihatahon mai! }\end{array}$ & $\begin{array}{c}\text { Dapot ko do holi na } \\
\text { ihatahon mai! }\end{array}$ \\
\hline 7 & 7 & 7 & 7 & 5 \\
\hline
\end{tabular}

\subsection{Swearing Taboo Word Category}

In the (e) swearing, fifteen words, namely (1) babahmin, (2) bapakmu, (3) jolma baliang, (4) jolma binatang, (5) jolma bodat, (6) jolma toi, (7) kurang ajar, (8) mamakmu, (9) matamin, (10) muliah ma ho, (11) oppungmin, (12) songon binatang, (13) songon bodat, (14) songon mossi, (14) songon fais, dan (16) tois kubam

Table 4.5. Swearing Taboo Word Category

\begin{tabular}{|c|c|c|c|c|}
\hline \multicolumn{5}{|c|}{ Swearing } \\
\hline $1930-1940$ & 1941-1960 & $1961-1980$ & $1981-2000$ & $2001-2021$ \\
\hline Babah min! & Babah min! & Babah min! & Babah min! & Babah min! \\
\hline Bapamu! & Bapakmu! & Bapakmu! & Bapakmu! & Bapakmu! \\
\hline Buatan ni polong! & Buatan ni polong! & Buatan ni polong! & Buatan ni polong! & Not Used \\
\hline Buatan ni sampar! & Buatan ni sampar! & Buatan ni sampar! & Buatan ni sampar! & Not Used \\
\hline Jolma baliang! & Jolma baliang! & Jolma baliang! & Jolma baliang! & Jolma baliang! \\
\hline Jolma binatang! & Jolma binatang! & Jolma binatang! & Jolma binatang! & Jolma binatang! \\
\hline Jolma bodat! & Jolma bodat! & Jolma bodat! & Jolma bodat! & Jolma bodat! \\
\hline Jolma Huting! & Jolma Huting! & Jolma Huting! & Jolma Huting! & Not Used \\
\hline Jolma Lontong! & Jolma na lontong! & Jolma na lontong! & Jolma na lontong! & Not Used \\
\hline Jolma Pais! & Jolma Paes! & Jolma Paes! & Jolma Paes! & Not Used \\
\hline Jolma na tarulang! & Not Used & Not Used & Not Used & Not Used \\
\hline Jolma toi! & Jolma toi & Jolma toi & Jolma toi! & Jolma toi! \\
\hline Kurang ajar! & Kurang ajar! & Kurang ajar! & Kurang ajar! & Kurang ajar! \\
\hline Mamakmu! & Mamakmu! & Mamakmu! & Mamakmu! & Mamakmu! \\
\hline Matamin! & Matamin! & Matamin! & Matamin! & Matamin! \\
\hline Mulih ma ho! & Mulih ma ho! & Mulih ma ho! & Mulih ma ho! & Mulih ma ho! \\
\hline Oppungmu! & Oppungmu! & Oppungmu! & Oppungmu! & Oppungmu! \\
\hline Songon binatang! & Songon binatang! & Songon binatang! & Songon binatang! & Songon binatang! \\
\hline Songon bodat! & Songon bodat! & Songon bodat! & Songon bodat! & Songon bodat! \\
\hline Songon mossi! & Songon mossi! & Songon mossi! & Songon mossi! & Songon mossi! \\
\hline Songon pais! & Songon paes! & Songon paes! & Songon paes! & Songon paes! \\
\hline Tambur kaes! & Tambur kaes! & Tambur kaes! & Tambur kaes! & Not Used \\
\hline Tangkuhukmin! & Tangkuhukmin! & Tangkuhukmin! & Tangkuhukmin! & Not Used \\
\hline Tois ku bam! & Tois ku bam! & Tois ku bam! & Tois ku bam! & Tois ku bam! \\
\hline Tolnangmu! & Tolnangmu! & Tolnangmu! & Tolnangmu! & Not Used \\
\hline Ulumin! & Ulumin! & Ulumin! & Ulumin! & Not Used \\
\hline 26 & 25 & 25 & 25 & 17 \\
\hline
\end{tabular}

\subsection{Calling People Taboo Word Category}

Only eight words are used consistently in calling people taboo (from 1930 to 2021): (1) goran ni bapak diri, (2) goran ni parmaen, (3) goran ni mamak diri, (4) goran ni makhela diri, (5) goran namboru diri, (6) goran tulang, (7) goran ni atturang, and (8) goran ni lae diri. 
Table 4.6. Calling Taboo Word Category

\begin{tabular}{|c|c|c|c|c|}
\hline \multicolumn{7}{|c|}{ Calling Taboo Word Category } \\
\hline $1930-1940$ & $1941-1960$ & $1961-1980$ & $1981-2000$ & $2001-2021$ \\
\hline Goran ni besan & Goran ni besan & Goran ni besan & Goran ni besan & Not Used \\
\hline Goranni bapak diri. & Goranni bapak diri & Goranni bapak diri & Goranni bapak diri & Goranni bapak diri. \\
\hline Goran ni datu & Goran ni datu & Goran ni datu & Goran ni datu & Not Used \\
\hline Goran ni parmaen & Goran ni parmaen & Goran ni parmaen & Goran ni parmaen & Goran ni parmaen \\
\hline Goranni mamak diri & Goranni mamak diri & Goranni mamak diri & Goranni mamak diri & Goranni mamak diri \\
\hline Goranni makkela diri & Goranni makkela diri & Goranni makkela diri & Goranni makkela diri & Goranni makkela diri \\
\hline Goranni namboru diri & Goranni amboru diri & Goranni namboru diri & Goranni namboru diri & Goranni namboru diri \\
\hline Goran ni raja & Goran ni raja & Goran ni raja & Goran ni raja & Not Used \\
\hline Goran ni tulang & Goran ni tulang & Goran ni tulang & Goran ni tulang & Goran ni tulang \\
\hline Goran ni atturang & Goran ni atturang & Goran ni atturang & Goran ni atturang & Goran ni atturang \\
\hline Goran ni lae diri & Goran ni lae diri & Goran ni lae diri & Goran ni lae diri & Goran ni lae diri \\
\hline 11 & 11 & 11 & 11 & 8 \\
\hline
\end{tabular}

\subsection{Action Taboo Word Category}

In the category of action taboo word, there are only sixteen words are used stably across time (from 1930 - 2021), namely: (1) dalan-dalan, (2) kawin senmarga, (3) manulluk halak, (4) manghunduli battal, (5) manghunduli losung, (6) maridi i tapian, (7) marjanji laho hujuma borngin ni ari, (8) riap maridi pakon lae, (9) marangan angan i harangan, (10) mambungkili, (11) muntut, (12) mambere imbul-imbul hubani tondong, (13) pajobu-jobuon, (14) paingor ingorhon, (15) pasambor-samborhon, and (16) tartawa bani halak namabuei.

Table 4.7. Action Taboo Word Category

\begin{tabular}{|c|c|c|c|c|}
\hline \multicolumn{5}{|c|}{ Action } \\
\hline $1930-1940$ & $1941-1960$ & $1961-1980$ & $1981-2000$ & $2001-2021$ \\
\hline Dalan-dalan & Dalan-dalan & Dalan-dalan & Dalan-dalan & Dalan-dalan \\
\hline $\begin{array}{c}\text { Ijai do ibahen ho } \\
\text { lonsot ase idagei ho } \\
\text { samei in } \\
\end{array}$ & $\begin{array}{c}\text { Ijai do ibahen ho } \\
\text { lonsot ase idagei ho } \\
\text { samei in } \\
\end{array}$ & $\begin{array}{c}\text { Ijai do ibahen ho } \\
\text { lonsot ase idagei ho } \\
\text { samei in } \\
\end{array}$ & $\begin{array}{c}\text { Ijai do ibahen ho lonsot ase } \\
\text { idagei ho samei in }\end{array}$ & Not used \\
\hline Kawin semarga & Kawin semarga & Kawin semarga & Kawin semarga & Kawin semarga \\
\hline Manulluk Halak & Manulluk Halak & Manulluk Halak & Manulluk Halak & Manulluk Halak \\
\hline Menghunduli bantal & Menghunduli bantal & Menghunduli bantal & Menghunduli bantal & Menghunduli bantal \\
\hline Manghunduli losung & Manghunduli losung & Manghunduli losung & Manghunduli losung & Manghunduli losung \\
\hline $\begin{array}{l}\text { Maridi i tapian bani } \\
\text { tongah ari }\end{array}$ & $\begin{array}{l}\text { Maridi i tapian bani } \\
\text { tongah ari }\end{array}$ & $\begin{array}{l}\text { Maridi i tapian bani } \\
\text { tongah ari }\end{array}$ & $\begin{array}{l}\text { Maridi i tapian bani tongah } \\
\text { ari }\end{array}$ & $\begin{array}{l}\text { Maridi i tapian bani } \\
\text { tongah ari }\end{array}$ \\
\hline $\begin{array}{l}\text { Marjanji laho hujuma } \\
\text { bani borgin ni ari }\end{array}$ & $\begin{array}{l}\text { Marjanji laho hujuma } \\
\text { bani borgin ni ari }\end{array}$ & $\begin{array}{c}\text { Marjanji laho hujuma } \\
\text { bani borgin ni ari }\end{array}$ & $\begin{array}{l}\text { Marjanji laho hujuma bani } \\
\text { borgin ni ari }\end{array}$ & $\begin{array}{c}\text { Marjanji laho hujuma } \\
\text { bani borgin ni ari }\end{array}$ \\
\hline Maridi riap pakon lae & Maridi riap pakon lae & Maridi riap pakon lae & Maridi riap pakon lae & Maridi riap pakon lae \\
\hline $\begin{array}{c}\text { Marjanji bani } \\
\text { panorang samon } \\
\text { (pergantian } \\
\text { sore/malam) }\end{array}$ & $\begin{array}{c}\text { Marjanji bani } \\
\text { panorang samon } \\
\text { (pergantian } \\
\text { sore/malam) }\end{array}$ & $\begin{array}{c}\text { Marjanji bani } \\
\text { panorang samon } \\
\text { (pergantian } \\
\text { sore/malam) }\end{array}$ & $\begin{array}{c}\text { Marjanji bani panorang } \\
\text { samon (pergantian } \\
\text { sore/malam) }\end{array}$ & Not used \\
\hline $\begin{array}{c}\text { Marangan-angan i } \\
\text { harangan }\end{array}$ & $\begin{array}{c}\text { Marangan-angan i } \\
\text { harangan }\end{array}$ & $\begin{array}{l}\text { Marangan-angan i } \\
\text { harangan }\end{array}$ & Marangan-angan i harangan & $\begin{array}{l}\text { Marangan-angan i } \\
\text { harangan }\end{array}$ \\
\hline Marsummah & Marsummah & Marsummah & Marsummah & Marsummah \\
\hline Muttut & Muttut & Muttut & Muttut & Muttut \\
\hline $\begin{array}{l}\text { Mambere inbul-inbul } \\
\text { hubani tondong }\end{array}$ & $\begin{array}{l}\text { Mambere inbul-inbul } \\
\text { hubani tondong }\end{array}$ & $\begin{array}{l}\text { Mambere inbul-inbul } \\
\text { hubani tondong }\end{array}$ & $\begin{array}{l}\text { Mambere inbul-inbul } \\
\text { hubani tondong }\end{array}$ & $\begin{array}{l}\text { Mambere inbul-inbul } \\
\text { hubani tondong }\end{array}$ \\
\hline Mambungkili & Not used & Not used & Not used & Not used \\
\hline Pajobu-jobuhon & Pajobu-jobuhon & Pajobu-jobuhon & Pajobu-jobuhon & Pajobu-jobuhon \\
\hline Paingor-ingorhon & Paingor-ingorhon & Paingor-ingorhon & Paingor-ingorhon & Paingor-ingorhon \\
\hline Pasambor-samborhon & Pasambor-samborhon & Pasambor-samborhon & Pasambor-samborhon & Pasambor-samborhon \\
\hline $\begin{array}{c}\text { Tartawa bani halak na } \\
\text { mabuei }\end{array}$ & $\begin{array}{c}\text { Tartawa bani halak na } \\
\text { mabuei }\end{array}$ & $\begin{array}{c}\text { Tartawa bani halak na } \\
\text { mabuei }\end{array}$ & $\begin{array}{c}\text { Tartawa bani halak na } \\
\text { mabuei }\end{array}$ & $\begin{array}{c}\text { Tartawa bani halak na } \\
\text { mabuei }\end{array}$ \\
\hline 19 & 18 & 18 & 18 & 16 \\
\hline
\end{tabular}

\subsection{Disease Taboo Word Category}

In the category of disease, only one word was used stably across times (from 1930 - 2021), namely gadam. 
Table 4.8. Disease Taboo Word Category

\begin{tabular}{|c|c|c|c|c|}
\hline \multicolumn{5}{|c|}{ Disease } \\
\hline 1930-1940 & $1941-1960$ & $1961-1980$ & $1981-2000$ & 2001-2021 \\
\hline Gadam & Gadam & Gadam & Gadam & Gadam \\
\hline Sipilis & Sipilis & Sipilis & Sipilis & Not Used \\
\hline Sampar & Sampar & Sampar & Sampar & Not Used \\
\hline 3 & 3 & 3 & 3 & 1 \\
\hline
\end{tabular}

\subsection{Taboo Word Dwelling Ghost Category}

In the category of dwelling ghost, there are only two words are used stably across time (from 1930 - 20210, they are (1) begu matei and (2) begu ganjang

Table 4.9. Taboo Word Dwelling Ghost Category

\begin{tabular}{|c|c|c|c|c|}
\hline \multicolumn{5}{|c|}{ Taboo Word Dwelling Ghost Category } \\
\hline $1930-1940$ & $1941-1960$ & $1961-1980$ & $1981-2000$ & $2001-2021$ \\
\hline Begu Matei & Begu Matei & Begu Matei & Begu Matei & Begu Matei \\
\hline Begu Banggal & Begu Banggal & Begu Banggal & Begu Banggal & Not used. \\
\hline Begu Ganjang & Begu Ganjang & Begu Ganjang & Begu Ganjang & Begu Ganjang \\
\hline Begu na so tongka & Begu na so tongka & Begu na so tongka & Begu na so tongka & Not Used \\
\hline Begu salih-salihan & Begu salih-salihan & Begu salih-salihan & Begu salih-salihan & Not Used \\
\hline 5 & 5 & 5 & 5 & 2 \\
\hline
\end{tabular}

\subsection{God's Name Taboo Word Category}

In the category of name of God, only one word is used stably (1930 - 2021), namely Naibata.

Table 4.10. God's Name Taboo Word Category

\begin{tabular}{|c|c|c|c|c|}
\hline \multicolumn{5}{|c|}{ God's Name Taboo Word Category } \\
\hline 1930-1940 & $1941-1960$ & $1961-1980$ & $1981-2000$ & $2001-2021$ \\
\hline Naibata/Tuhan & Naibata/Tuhan & Naibata/Tuhan & Naibata/Tuhan & Naibata/Tuhan \\
\hline 1 & 1 & 1 & 1 & 1 \\
\hline
\end{tabular}

\section{Conclusion}

Based on the findings above, it can be concluded that there are 106 words ever known as taboo words in the ten categories in Simalungunese and only 62 are stably known up to the present time. It is concluded that taboo words are mostly changing not static over time. Taboo words in Simalungun change with the development of human society in order to meet the need of humans for communication, and they are closely related to Simalungun culture and the specific context of communication.

\section{References}

Allan, K., \& Burridge, K. (2006). Forbidden words: Taboo and the censoring of language. Cambridge: Cambridge University Press. https://doi.org/10.1017/CBO9780511617881

Azmi, N. A., Hua, T. K., Abdullah, I. H., \& Azman, H. (2021). The efficacy of Kibbitzer in solving specific language problems among ESL undergraduates. International Journal of English Language and Literature Studies, 10(2), 83-93. https://doi.org/10.18488/journal.23.2021.102.83.93

Bloomfield, L. (1964). Language. New York: Holt, Rinehart and Winston.

Bogdan, R. C., \& Biklen, S. K. (1982). Qualitative research for education: An introduction to theory and methods. Boston: Allyn and Bacon Inc.

Crystal, D. (1992). The Cambridge encyclopedia of English language. New York: Cambridge University Press.

Gramley, S., \& Pätzold, K. M. (1992). A survey of modern English. London: Routledge.

Hashimee, N. (2020). Studying the application of signification in linguistics and logic. International Journal of Innovative Research and Scientific Studies, 3(4), 135-141. https://doi.org/10.53894/ijirss.v3i4.47

Herman, Murni, S. M., Sibarani, B., \& Saragih, A. (2019). Structures of representational metafunctions of the "Cheng Beng" Ceremony in Pematangsiantar: A multimodal analysis. International Journal of Innovation, 
Creativity and Change, 8(4), 34-46.

Herman, V. T. N., \& Purba, N. A. (2021). Investigating sentence fragments in comic books: A syntactic perspective. World Journal of English Language, 11(2), 139-151. https://doi.org/10.5430/wjel.v11n2p139

Hudson, R. A. (1982). Sociolinguistics. London: Cambridge University Press.

Jay, T. (1992). Cursing in America: A psycholinguistic study of dirty language in the courts, in the movies, in the schoolyards and on the streets. Philadelphia: Benjamins. https://doi.org/10.1075/z.57

Madzlan, N. A., Seng, G. H., \& Kesevan, H. V. (2020). Use of video blogs in alleviating public speaking anxiety among ESL learners. Journal of Education and E-Learning Research, 7(1), 93-99. https://doi.org/10.20448/journal.509.2020.71.93.99

Mercury, R. E. (1995). Swearing: A bad part of language \& a good part of language learning. TESL, Canada Journal, 13(1), 28-36. https://doi.org/10.18806/tesl.v13i1.659

Mpofu, N., \& Maphalala, M. C. (2020). Pedagogical practices involved in integrating English language skills in subject-specific learning: A case of high school teachers. International Journal of Education and Practice, 8(4), 664-675. https://doi.org/10.18488/journal.61.2020.84.664.675

Pilcher, W. W. (1972). The portland longshoremen: A dispersed urban community. New York: Holt, Rinehart and Winston.

Purba, R. (1998). Linguistic Taboo in Simalungun: A sociolinguistic study. Unpublished Master's Thesis. Malang: Post Graduate Program in English Education.

Purba, R., \& Herman. (2020). Multimodal analysis on Ertiga car advertisement. Wiralodra English Journal (WEJ), 4(1), 21-32. https://doi.org/10.31943/wej.v4i1.77

Qasemi, A. S. (2020). Factors affecting students' speaking performance in English department of Jawzjan University. International Journal of Innovative Research and Scientific Studies, 3(4), 129-134. https://doi.org/10.53894/ijirss.v3i4.46

Saragih, J. (1979). The impact of Christianization in Simalungun, North Sumatera 1903-1963. Unpublished Master Theses. Australia: The University of Sydney.

Saragih, V. (1981). Group work students to teach students: A motivating factor in developing communicative skills. Skripsi Thesis, Sanata Dharma University.

Steiner, F. (1956). Taboo. London: Cohen and West. https://doi.org/10.1097/00010694-195610000-00028

Sukirlan, M., Raja, P., Setiyadi, A., \& Agustin, F. (2020). Developing strategy use and language performance through implicit strategy training. Humanities and Social Sciences Letters, 8(2), 191-201. https://doi.org/10.18488/journal.73.2020.82.194.201

Trudgill, P. (2000). Sociolinguistics: An introduction to language and society. UK: Penguin.

Van Thao, N., Herman, Ha, T. T., Thuy, N. T. T., \& Tho, N. T. Q. (2020). Analysis of argumentation in Nam Cao's Story 'Chi Pheo' based on a pragmatics perspective. International Journal of Innovation, Creativity and Change, 12(12), 931-948.

Van Thao, N., Herman, Napitupulu, E. R., Hien, N. T., \& Pardede, H. (2021). Code-switching in learning via zoom application: A study in an EFL context. Asian ESP Journal, 17(3.1), 91-111.

Wardhaugh, K. G. (1986). Diapause strategies in the Australian plague locust (Chortoicetes terminifera Walker). In The evolution of insect life cycles (pp. 89-104). New York: Springer. https://doi.org/10.1007/978-1-4613-8666-7_6

Webster, H. (1942). Taboo: A sociological study. London: Humphrey Milford Oxford University Press.

\section{Copyrights}

Copyright for this article is retained by the author(s), with first publication rights granted to the journal.

This is an open-access article distributed under the terms and conditions of the Creative Commons Attribution license (http://creativecommons.org/licenses/by/4.0/). 